\title{
Meningkatkan Kemampuan Menulis Descriptive Text Menggunakan Metode Picture and Picture
}

\author{
Ilham Prasetyo ${ }^{*}$ \\ ${ }^{1}$ Program Studi Bahasa dan Sastra Inggris, Universitas Pendidikan Ganesha, Singaraja, Indonesia
}

\section{ART I C LE IN F O}

Article history:

Received July 16, 2021

Revised July 20, 2021

Accepted September 20, 2021

Available online November 25, 2021

Kata Kunci:

Descriptive Text, Picture and

Picture, Keterampilan Menulis

Keywords:

Descriptive Text, Picture, and Picture, Writing Skills

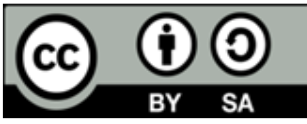

This is an open access article under the CC BY-SA license.

Copyright () 2021 by Author. Published by Universitas Pendidikan Ganesha.

\begin{abstract}
A B S T R A K
Menulis merupakan salah satu keterampilan yang harus dimiliki peserta didik, kususnya pada mata pelajaran bahasa Inggris. Hanya saja kenyataan di lapangan menunjukkan bahwa kemampuan menulis descriptive text siswa pada mata pelajaran bahasa Inggris masih sangat rendah. Dari permasalahan tersebut, tujuan dari penelitian ini yakni untuk mengertahui peningkatan kemampuan siswa menulis descriptive text setelah belajar menggunakan metode picture and picture. Penelitian ini merupakan jenis penelitian tindakan kelas yang dilaksanakan dalam 2 siklus penelitian. Setiap siklus penelitian terdiri dari 4 fase, dia ntaranya adalah perencanaan, pelaksanaan tindakan, pengamatan, dan refleksi. Subjek yang terlibat dalam penelitian ini yakni 36 orang siswa SMK. Pengumpulan data dalam penelitian dilakukan dengan Hasil penelitian dianalisis dengan menggunakan analisis deskriptif kualitatif dan deskriptif kuantitatif. Hasil yang diperoleh dalam penelitian ini menunjukkan bahwa hasil belajar siswa pada kompetensi pengetahuan dan kompetensi menulis dalam proses pembelajaran siklus pertama sebesar $81,80 \%$ dan $73,05 \%$. Pada siklus kedua hasil belajar siswa pada kompetensi menulis sebesar $84,02 \%$. Dapat disimpulkan bahwa penerapan metode picture and picture dapat meningkatkan kemampuan menulis descriptive text pada siswa kelas X SMK.
\end{abstract}

\section{ABS TRACT}

Writing is one of the skills that students must possess, especially in English subjects. However, the reality on the ground shows that students' ability to write descriptive text in English subjects is still meager. From these problems, this study aims to determine the effect of the Picture and Picture method on students' writing descriptive text skills. This research is a type of classroom action research that is carried out in 2 research cycles. Each research cycle consists of 4 phases: planning, implementing actions, observing, and reflecting. The subjects involved in this study were 36 SMK students. Data collection in the study was carried out using the methods of observation, interviews, questionnaires, and tests. The research data were then analyzed using qualitative and quantitative descriptive analyses. The results obtained in this study indicate that student learning outcomes on knowledge competence and writing competence in the first cycle of the learning process are $81.80 \%$ and $73.05 \%$, respectively. In the second cycle, student learning outcomes in writing competence were $84.02 \%$. So based on the data from the classroom action research, it can be concluded that applying the picture and picture method can improve the ability to write descriptive text in class $X$ SMK students.

\section{PENDAHULUAN}

Menulis merupakan suatu keterampilan berbahasa yang digunakan untuk berkomunikasi seara tidak langsung, produktif, ekspresif dengan memanfaatkan struktur bahasa, dan kosa kata (Juariah et al., 2021; Sunariati et al., 2019; Taufiqurrohman \& Hasbullah, 2020). Menulis juga merupakan suatu kegiatan yang produktif dan ekspresif (Erviana et al., 2021; Putri et al., 2021). Ekspresif dalam arti bahwa dengan menulis, siswa dapat mengekspresikan danmengungkapkan ide, gagasan, dan pengalaman untuk dikomunikasikan kepada orang lain (Lestari et al., 2020). Menulis dipengaruhi oleh keterampilan produktif lainnya, seperti aspek berbicara maupun keterampilan reseptif yaitu aspek membaca dan menyimak serta pemahaman kosakata, diksi, keefektifan kalimat, penggunaan ejaan, dan tanda baca 
(Endang \& Fitriani, 2019; Mahmur et al., 2021). Keterampilan menulis tidak akan datang secara otomatis, melainkan harus melalui latihan dan praktik yang banyak dan teratur (Prakoso et al., 2021). Untuk meningkatkan kemampuan menulis, seseorang harus melakukan latihan secara terus menerus tanpa putus asa. Ketika menemui suatu masalah, siswa tidak langsung menyerah melainkan mencari solusi untuk mengatasinya. Keterampilan menulis menjadi salah satu keterampilan yang harus dimiliki oleh siswa SMK. Salah satu keterampilan menulis yang harus dikuasai oleh siswa yakni keterampilan menulis teks deskripsi (description text). Teks deskripsi merupakan salah satu jenis teks yang berisi pemaparan tentang suatu hal atau fenomena (Lusita \& Emidar, 2019). Teks deskripsi menggambarkan secara jelas tentang objek, tempat atau peristiwa yang sedang menjadi topik kepada pembaca, sehingga pembaca merasakan langsung apa yang sedang diungkapkan dalam teks tersebut (Fitrianita \& Ramadhan, 2018). Dalam pembelajaran bahasa Inggris dalam jenjang SMK descriptive text (teks deskripsi) menjadi salah satu materi yang dibelajarkan kepada siswa.

Siswa cenderung mengalami kesulitan dalam mengikuti pembelajaran menulis descriptive text yang dilakukan untuk mengembangkan kemampuan siswa dalam menulis (Amalia \& Rusfandi, 2020; Suryono, 2020). Hanya saja berdasarkan kenyatan di lapangan menunjukkan bahwa tidak semua siswa mampu menulis descriptive text dengan baik ide-ide mereka menjadi sebuah descriptive text. Hal ini sejalan dengan hasil observasi yang telah dilakukan di SMK Negeri 1 Singaraja. Hasil observasi menunjukkan bahwa kemampuan siswa dalam menulis sangat rendah. Nilai rata-rata siswa adalah 52.86 dari 100 dibandingkan dengan nilai KKM yaitu 70. Berdasarkan hasil wawancara bersama siswa, rendahnya kemampuan menulis descriptive text cenderung disebabkan oleh kurangnya kemampuan siswa dalam menemukan ide serta menyampaikan ide pokok dari sebuah cerita untuk membangun sebuah descriptive text. Mereka cenderung menuliskan sebuah descriptive text singkat untuk sebuah cerita yang mereka tulis atau lebih dari dua ide pokok dalam sebuah cerita. Yang kedua, terdapat banyak kesalahan dalam penulisan kalimat, seperti tidak menggunakan present tense, kesalahan pengejaan contohnya (table/tabel), serta tanda baca yang tidak tepat seperti penggunaan titik(.) dan koma (,) yang sesuai, dan juga penggunaan huruf besar dalam tulisannya. Descriptive text yang dibuat sangat minim kosa kata dan kebanyakan kalimat masih diterjemahkan kata perkata. Selain itu, kurangnya kemampuan menulis siswa juga disebabkan oleh ketidaksukaan siwa akan cara guru mengajarkan descriptive text. Guru hanya memberikan topik kemudian meminta siswa untuk menulis tanpa memberikan waktu pada mereka untuk berpikir tentang apa yang akan mereka tuliskan. Hal ini yang mengakibatkan para siswa merasa tidak tertarik untuk menulis. Jika dibiarkan secara terus menerus, permasalahan ini akan berdampak pada semakin menurunnya kemampuan menulis siswa.

Upaya yang dapat dilakukan untuk mengatasi masalah tersebut yakni dengan menggunakan metode pembelajaran yang sesuai dengan kebutuhan siswa. Salah satu metode pembelajaran yang dapat meningkatkan kemampuan menulis descriptive text siswa yakni metode pembelajaran picture and picture. Picture and picture merupakan salah satu metode pembelajaran yang menggunakan peran gambar yang dipasangkan atau diurutkan menjadi urutan logis berdasarkan tujuan pembelajaran (Fatimah, 2021; Kamtini et al., 2021; Syauki et al., 2021). Model pembelajaran ini mengandalkan gambar sebagai media utama dalam proses pembelajaran. Melalui gambar-gambar yang disediakan siswa akan mampu dan lebih mudah dalam memahami materi pembelajaran yang disampaikan oleh guru, selain itu siswa akan mampu mengetahui hal-hal yang belum pernah dilihatnya (N. N. K. Dewi et al., 2019). Dalam proses belajar menulis, model picture and picture akan dapat membantu siswa dalam mengembangkan ide-ide yang kemudian dituangkan dalam tulisannya. Beberapa penelitian yang telah dilakukan sebelumnya menyebutkan bahwa model pembelajaran picture and picture berbasis portofolio berpengaruh terhadap hasil belajar IPA siswa kelas V Sekolah Dasar (Purwani et al., 2018). Hasil penelitian lainnya juga menyebutkan bahwa model Picture and Picture dapat meningkatkan keterampilan guru dalam mengajar, meningkatkan peran aktif siswa, serta meningkatkan keterampilan menulis deskripsi siswa kelas II Sekolah Dasar (Sholeh et al., 2021). Penelitian selanjutnya juga menyatakan bahwa model pembelajaran picture and picture efektif dan dikategorikan dengan baik untuk meningkatkan kemampuan menulis cerita pendek (Musyafa, 2020). Berdasarkan beberapa hasil penelitian tersebut dapat dikatakan bahwa penggunaan model picture and picture sangat efektif digunakan untuk meningkatkan kemampuan menulis siwa. Hanya saja pada penelitian sebelumnya belum terdapat kajian mengenai penggunaan model picture and picture untuk meningkatkan kemampuan menulis descriptive text siswa SMK. Oleh karena itu, penelitian ini difokuskan pada kajian tersebut dengan tujuan untuk mengetahui peningkatan hasil belajar siswa menulis descriptive text setelah belajar menggunakan metode picture and picture. 


\section{METODE}

Penelitian ini menggunakan rancangan penelitian tindakan kelas. Penelitian tindakan kelas merupakan penilitian yang dilakukan seorang guru di dalam kelas dengan melakukan tindakan tertentu dengan tujuan untuk memecahkan masalah yang sedang dihadapai oleh guru dalam pembelajaran. Penelitian tindakan kelas dilakukan dalam beberapa siklus penelitian. Pada setiap siklus terdapat 4 tahapan penelitian yang terdiri dari planning, action, observation, dan reflection. Pada fase planning, peneliti memulai dengan mengidentifikasi masalah selanjutnya dikembangkan menjadi sebuah perencanaan tindakan yang dikembangkan dalam satu area khusus. Action adalah fase mengimplementasi perencanaan ke dalam proses pembelajaran di dalam kelas. Observation merupakan tahap untuk mengobservasi pengaruh dari tindakan yang diberikan. Tahap ini juga disebut sebagai tahap pengumpulan data menggunakan alat untuk mengumpulkan informasi tentang apa yang sedang terjadi. Fase terakhir adalah reflection yakni fase refleksi atau evaluasi dan menjelaskan perubahan dari tindakan yang diberikan dalam rangka untuk memahami masalah yang terjadi.

Subjek yang terlibat dalam penelitian ini yakni siswa kelas X-A SMK Negeri 1 Singaraja yang berjumlah 36 orang, terdiri terdiri dari 15 orang laki-laki dan 21 orang perempuan. Pengumpulan data dilakukan dengan menggunakan tiga metode yaitu metode observasi, metode tes, dan metode angket. Analisis data hasil penelitian dilakukan dengan menggunakan analisis deskriptif kualitatif dan deskriptif kuantitatif. Kriteria keberhasilan digunakan sebagai patokan dalam mengakhiri penelitian ini adalah sebagai berikut. Pertama, kriteria keberhasilan hasil belajar keterampilan menulis descriptive text ditunjukkan dengan adanya keberhasilan pemerolehan skor rata-rata kelas pada kategori baik atau $75 \%$ dari jumlah keseluruhan peserta didik memeroleh nilai kategori baik dan jumlah klasikal kelulusan 100\%. Kedua, kriteria respons peserta didik ditunjukkan oleh perolehan persentase $75 \%$ dari jumlah keseluruhan peserta didik merespons positif atau senang dengan tindakan pembelajaran. Dengan tercapainya kriteria keberhasilan yang telah ditentukan di atas, penelitian dihentikan. Siklus tindakan yang mampu mencapai kriteria keberhasilan tersebut sekaligus dianggap sebagai tindakan terbaik.

\section{HASIL DAN PEMBAHASAN}

\section{Hasil}

Penelitian ini dilakukan sebanyak 2 siklus. Pada siklus pertama 2 kali pertemuan dan pada siklus kedua sebanyak 1 kali pertemuan. Pelaksanaan siklus I berdasarkan hasil observasi awal yang menunjukkan bahwa dari 36 siswa, yang berada pada predikat sangat baik tidak ada, baik 3 orang, cukup 4 orang (11.11\%), dan kurang sebanyak 29 orang (80.56\%). Berdasarkan hasil tersebut, maka dilaksanakan penelitian pada siklus I. Hasil penelitian pada siklus I dengan materi menulis descriptive text menunjukkan bahwa pada kompetensi pengetahuan 36 orang sudah tuntas dengan rata-rata klasikal 81.80, kompetensi keterampilan 22 orang sudah tuntas dengan rata-rata nilai secara klasikal 73.05. Ini berarti bahwa penelitian pada siklus I belum berhasil. Dari kedua kompetensi yang dinilai yaitu kompetensi pengetahuan dan kompetensi keterampilan masih ada peserta didik yang belum memenuhi KKM yaitu 70, sehingga belum memenuhi ketuntasan belajar secara klasikal $100 \%$. Kurang maksimalnya hasil yang diperoleh pada siklus I disebabkan oleh belum mampunya peserta didik mengurutkan gambargambar dengan benar, sehingga tidak dapat menjelaskan dengan baik dalam bentuk descriptive text. Di samping itu, peserta didik belum mampu membuat kalimat present tense dengan benar. Berdasarkan permasalahan yang menyebabkan belum tercapainya kriteria keberhasilan yang ditetapkan, maka penelitian ini dilanjutkan ke siklus II dengan perbaikan.

Hasil pelaksanaan siklus II menunjukkan bahwa pada kompetensi keterampilan menulis descriptive text 36 orang sudah tuntas dengan rata-rata nilai secara klasikal 84.02. Hasil ini sudah mencapai kriteria keberhasilan yakni $75 \%$ dari jumlah keseluruhan peserta didik memeroleh nilai kategori baik, memenuhi KKM yaitu 70 dan memenuhi ketuntasan belajar secara klasikal 100\%. Peningkatan hasil belajar pada siklus II tersebut dikarenakan pengaplikasian pendekatan saintifik dan penggunaan metode picture and picture dengan pembelajaran kelompok dan mendiskusikan masalah yang menjadi topik descriptive text. Di samping itu, juga dilakukan perbaikan berdasarkan kendala pada siklus I. Penelitian kemudian dilanjutkan pada penyebaran angket mengenai respon siswa terhadap proses pembelajaran. Hasil yang diperoleh pada penyebaran angket menunjukkan bahwa dari 36 orang siswa 22 orang di antaranya memberikan respon sangat positif dengan jumlah persentase sebesar $61,11 \%$ dan 14 orang lainnya memberikan respon positif dengan jumlah persentase sebesar 38,89\%. 


\section{Pembahasan}

Hasil analisis penelitian menunjukkan bahwa kemampuan siswa dalam menulis descriptive text pada materi bahasa Inggris semakin meningkat pada tiap siklusnya. Peningkatakan keterampilan menulis siswa tidak terlepas dari penggunaan metode pembelajaran picture and picture karean pada penerapan metode picture and picture guru menggunakan gambar sebagai media pembelajaran (Anggraini et al., 2019; Prihatiningsih \& Setyanigtyas, 2018; Sulfemi \& Minati, 2018). Gambar menjadi komponen penting dalam metode ini. Penggunaan gambar dalam metode picture and picture akan dapat merangsang proses berpikir siswa, sehingga mampu menciptakan ide-ide kreatif berdasarkan gambar yang diberikan (Fuldiaratman \& Minarni, 2021; Sukmawati \& Dantes, 2019). Penggunaan metode picture and picture sangat sesuai digunakan untuk membantu proses pembelajaran menulis siswa karena keterampilan menulis merupakan keterampilan yang paling sulit dikuasai oleh siswa (Aldrina \& Abdurrahman, 2020; Musyafa, 2020; Ngadino, 2018; Puspasari \& Setyaningsih, 2020). Menulis merupakan keterampilan akhir yang harus dikuasai oleh siswa setelah keterampilan menyimak dan berbicara (Gustina, 2019; Sari, 2018). Kegiatan menulis tidak dapat dilakukan secara sembarangnya melainkan melalui proses menyimak dan membaca berbagai informasi yang ada (Yuliana, 2020). Seseorang dikatakan mampu menulis dengan baik apabila telah mampu menguasai keterampilan reseptif yaitu aspek membaca dan menyimak serta pemahaman kosakata, diksi, keefektifan kalimat, penggunaan ejaan, dan tanda baca (Dewi \& Simbolon, 2021). Keterampilan menulis tidak akan datang secara otomatis, melainkan harus melalui latihan dan praktik yang banyak dan teratur.

Pembelajaran menulis pada jenjang pendidikan Sekolah Menengah Kejuruan (SMK) mengarahkan siswa untuk mampu menulis descriptive text dalam pembelajaran bahasa Inggris. Descriptive text merupakan salah satu jenis teks yang berisi pemaparan tentang suatu hal atau fenomena. Melalui teks deskripsi menggambarkan secara jelas tentang objek, tempat atau peristiwa yang sedang menjadi topik kepada pembaca, sehingga pembaca merasakan langsung apa yang sedang diungkapkan dalam teks tersebut (Fitrianita \& Ramadhan, 2018). Penggunaan metode picture and picture dalam pembelajaran menulis descriptive text sangatlah sesuai dengan kebutuhan siswa. Melalui gambar yang disediakan, siswa akan dapat mengembangkan berbagai ide untuk menyusun suatu teks deskriptif yang runtut. Hasil yang diperoleh pada penelitian ini sejalan dengan hasil penelitian terdahulu yang juga menyebutkan bahwa bahwa model pembelajaran picture and picture berbasis portofolio berpengaruh terhadap hasil belajar IPA siswa kelas V Sekolah Dasar (Purwani et al., 2018). Hasil penelitian lainnya juga menyebutkan bahwa model Picture and Picture dapat meningkatkan keterampilan guru dalam mengajar, meningkatkan peran aktif siswa serta meningkatkan keterampilan menulis deskripsi siswa kelas II sekolah dasar (Sholeh et al., 2021). Penelitian selanjutnya juga menyatakan bahwa model pembelajaran picture and picture efektif dan dikategorikan dengan baik untuk meningkatkan kemampuan menulis cerita pendek (Musyafa, 2020). Berdasarkan hasil penelitian yang didukung oleh penelitian sebelumnya dapat dilihat bahwa metode picture and picture sangat efektif digunakan dalam proses pembelajaran serta memperoleh respon positif dari siswa.

\section{SIMPULAN}

Terjadi peningkatkan keterampilan menulis descriptive text dengan diterapkannya metode picture and picture. Hal ini ditunjukkan pada kemampuan siswa menulis descriptive text pada materi bahasa Inggris semakin meningkat pada tiap siklusnya. Selain ini, penggunaan metode picture and picture sangat digemari oleh siswa, sehingga siswa menunjukkan respon yang sangat positif.

\section{DAFTAR RUJUKAN}

Aldrina, I., \& Abdurrahman, A. (2020). Pengaruh Penggunaan Model Picture And Picture Terhadap Keterampilan Menulis Teks Cerita Fantasi Siswa Kelas VII SMP Negeri 7 Pariaman. Pendidikan Bahasa Indonesia, 9(3), 29. https://doi.org/10.24036/108987-019883.

Amalia, R. D., \& Rusfandi, R. (2020). The Effectiveness of Problem-Based Learning in Improving Students' Writing Descriptive Text in Vocational School. Jurnal Inspirasi Pendidikan, 10(1), 1-11. https://doi.org/10.21067/jip.v10i1.3769.

Anggraini, R. dewi, Listyarini, I., \& Huda, C. (2019). Keefektifan Model Picture And Picture Berbantu Media Flashcard Terhadap Keterampilan Menulis Karangan. International Journal of Elementary Education, 3(1), 35. https://doi.org/10.23887/ijee.v3i1.17282.

Dewi, L. L., \& Simbolon, M. E. (2021). Pengaruh Penggunaan Metode Cooperative Script Terhadap Keterampilan Menulis Narasi Pada Muatan Bahasa Indonesia. Kamboti of Journal Education $\begin{array}{llll}\text { Research and } & \text { 2(1), }\end{array}$ 
https://ojs3.unpatti.ac.id/index.php/kamboti/article/view/4464/3359.

Dewi, N. N. K., Kristiantari, M. . R., \& Ganing, N. N. (2019). Pengaruh Model Pembelajaran Picture And Picture Berbantuan Media Visual Terhadap Keterampilan Menulis Bahasa Indonesia. Journal of Education Technology, 3(4), 278. https://doi.org/10.23887/jet.v3i4.22364.

Endang, E., \& Fitriani, Y. (2019). Analisis Kesalahan Penggunaan Bahasa Indonesia Dalam Laporan Hasil Observasi Pada Siswa SMA. Jurnal Pembahsi (Pembelajaran Bahasa Dan Sastra Indonesia), 9(1), 24. https://doi.org/10.31851/pembahsi.v9i1.4237.

Erviana, Y., Munifah, S., \& Mustikasari, R. (2021). Peningkatan Kemampuan Menulis Kata Dengan Ape Dadu Cerdas. Jurnal Mentari, https://jurnal.lppmstkipponorogo.ac.id/index.php/Mentari/article/view/129/169.

Fatimah, F. (2021). Peningkatan Hasil Belajar Siswa Melalui Penerapan Model Pembelajaran Picture and Picture pada Mata Pelajaran IPS Materi Masyarakat Indonesia pada Masa Praaksara di Kelas VII SMPN 2 Lambitu Semester 1 Tahun Pelajaran 2020/2021. Jurnal Pendidikan Dan Pembelajaran Indonesia (JPPI), 1(2), 351-360. https://doi.org/10.53299/jppi.v1i2.59.

Fitrianita, D., \& Ramadhan, S. (2018). Korelasi Keterampilan Memahami Teks Deskripsi Dengan Keterampilan Menulis Teks Deskripsi Siswa Kelas Vii Smp Negeri 15 Padang. Jurnal Pendidikan Bahasa Dan Sastra Indonesia, 7(3), 55-61. https://doi.org/10.31227/osf.io/e2gda.

Fuldiaratman, F., \& Minarni, M. (2021). Peningkatan Keaktifan dan Hasil Belajar Siswa Melalui Model Picture and Picture Berbantuan Media E-Komik. Journal of The Indonesian Society of Integrated Chemistry, 12(2), 62-67. https://doi.org/10.22437/jisic.v12i2.11087.

Gustina, G. (2019). Peningkatan Keterampilan Menulis Puisi Dengan Menggunakan Model Experiential Learning Pada Siswa Kelas III Sekolah Dasar. Jurnal Pendidikan Dan Konseling (JPDK), 1(1), 11-24. https://doi.org/10.31004/jpdk.v1i1.337.

Juariah, D., Arifin, E. Z., \& Suendarti, M. (2021). Pengaruh Minat Baca dan Penguasaan Kosakata terhadap Kemampuan Menulis Teks Eksposisi. Diskursus: Jurnal Pendidikan Bahasa Indonesia, 3(02), 110. https://doi.org/10.30998/diskursus.v3i02.7440.

Kamtini, K., Tanjung, S. H., \& Eriani, E. (2021). Mengenalkan Warna Melalui Model Pembelajaran Picture and Picture Pada Anak Usia Dini. Mitra Ash-Shibyan: Jurnal Pendidikan Dan Konseling, 4(02), 8190. https://doi.org/10.46963/mash.v4i02.233.

Lestari, D., Syambasri, \& Syahrani, A. (2020). Kemampuan Menulis Teks Persuasif Siswa Kelas VIII SMP Negeri 1 Sayan Kabupaten Melawi. Jurnal Pendidikan Dan Pembelajaran Khatulistiwa, 9(11), 1-9. https://jurnal.untan.ac.id/index.php/jpdpb/article/view/43422/75676587505.

Lusita, J., \& Emidar, E. (2019). Struktur Dan Unsur Kebahasaan Teks Deskripsi Siswa Kelas VII SMP Negeri 30 Padang. Pendidikan Bahasa Indonesia, 8(1), 113. https://doi.org/10.24036/103924-019883.

Mahmur, M., Hasbullah, H., \& Masrin, M. (2021). Pengaruh Minat Baca dan Penguasaan Kalimat terhadap Kemampuan Menulis Narasi. Diskursus: Jurnal Pendidikan Bahasa Indonesia, 3(02), 169. https://doi.org/10.30998/diskursus.v3i02.7408.

Musyafa, N. F. (2020). Penggunaan Model Picture and Picture dalam Pembelajaran Menulis Cerpen. Jurnal Bahasa, Sastra, Dan Pengajaran, 9(1), 37. https://doi.org/10.35194/alinea.v9i1.626.

Ngadino. (2018). Pembelajaran Keterampilan Menulis Narasi dengan Metode Picture and Picture pada Siswa Kelas Sekolah Dasar. Jurnal Stilistika, 4(2), 21-36. https://doi.org/10.32585/stilistika.v4i2.167.

Prakoso, A. R., Seriardana, P., \& Adnyani, L. D. S. (2021). Implementasi Genre Based Approach untuk Meningkatkan Keterampilan Menulis Explanation Text. Indonesian Gender and Society Journal, 2(1), 1. https://doi.org/10.23887/igsj.v2i1.39206.

Prihatiningsih, E., \& Setyanigtyas, E. W. (2018). Pengaruh Penerapan Model Pembelajaran Picture and Picture dan Model Make A Match terhadap Hasil Belajar Siswa. Jurnal Pendidikan Sekolah Dasar, 4(1), 1. https://doi.org/10.30870/jpsd.v4i1.1441.

Purwani, N. P. R., Darsana, I. W., \& Manuaba, I. B. S. (2018). Pengaruh Model Pembelajaran Picture and Picture Berbasis Portofolio terhadap Hasil Belajar IPA Siswa. International Journal of Elementary Education, 2(3), 165. https://doi.org/10.23887/ijee.v2i3.15955.

Puspasari, Q. K., \& Setyaningsih, N. H. (2020). Keefektifan Model Pembelajaran Picture and Picture dan Model Sugesti Imajinasi dalam Pembelajaran Menulis Puisi pada Siswa Kelas VIII SMP. Jurnal Pendidikan Bahasa Dan Sastra Indonesia, 9(1), 19-25. https://doi.org/10.15294/jpbsi.v9i1.27572.

Putri, E., Wulan, S., \& Siahaan, D. (2021). Strategi Pembelajaran Ekspositori terhadap Kemampuan Menulis Karangan Narasi. Jurnal Ilmu Pendidikan (JIP), 2(1), 49-53. https://jurnallp2m.umnaw.ac.id/index.php/JIP/issue/view/63.

Sari, V. O. (2018). Pengaruh Penggunaan Pendekatan Contextual Teaching and Learning terhadap Kemampuan Menulis Karangan Deskripsi pada Siswa Kelas X SMAN 4 Kotabumi. Parataksis: 
Jurnal Bahasa, Sastra, Dan Pembelajaran Bahasa Indonesia, 1(1). https://doi.org/10.31851/parataksis.v1i1.2252.

Sholeh, A., Veryliana, V., \& Darsimah, D. (2021). Meningkatkan Keterampilan Menulis Deskripsi dengan Model Picture and Picture di SDN 3 Bangkleyan Kabupaten Blora. Jurnal Paedagogy, 8(3), 454. https://doi.org/10.33394/jp.v8i3.3910.

Sukmawati, I., \& Dantes, D. (2019). Pengaruh Model Pembelajaran Picture and Picture terhadap Keterampilan Menulis Narasi. Mimbar PGSD Undiksha, $7(3)$. https://doi.org/10.23887/jjpgsd.v7i3.19390.

Sulfemi, W. B., \& Minati, H. (2018). Meningkatkan Hasil Belajar Peserta Didik Kelas 3 SD Menggunakan Model Picture and Picture dan Media Gambar Seri. Jurnal Pendidikan Sekolah Dasar, 4(2), 228. https://doi.org/10.30870/jpsd.v4i2.3857.

Sunariati, R., Ismawati, E., \& Riyadi, I. (2019). Hubungan antara Penguasaan Kosakata dan Struktur Kalimat dengan Kemampuan Menulis Karangan Narasi. Jurnal Pendidikan Bahasa, 8(2), 309. https://doi.org/10.31571/bahasa.v8i2.1564.

Suryono, S. (2020). Model Pembelajaran Discovery Learning pada Mata Pelajaran Bahasa Inggris untuk Meningkatkan Hasil Belajar pada Aspek Berbicara Materi Descriptive Text. Mimbar Pendidikan Indonesia, 1(2). https://doi.org/10.23887/mpi.v1i2.30187.

Syauki, A. Y., Astrianingsih, D., \& Khoiriyah, N. (2021). Peranan Model Pembelajaran Kooperatif Tipe Picture and Picture terhadap Keterampilan Menulis Paragraf Siswa SD. TULIP (Tulisan Ilmiah Pendidikan), 10(2), 69-84. https://doi.org/10.54438/tulip.v10i2.232.

Taufiqurrohman, T., \& Hasbullah, H. (2020). Pengaruh Penguasaan Kosakata dan Minat Belajar terhadap Kemampuan Menulis Teks Deskripsi (Survei pada MTs Swasta di Jakarta Selatan). Diskursus: Jurnal Pendidikan Bahasa Indonesia, 3(01), 55. https://doi.org/10.30998/diskursus.v3i01.6684.

Yuliana, Y. (2020). Pengaruh Minat Baca dan Penguasaan Kosakata terhadap Kemampuan Menulis Karangan Narasi. Diskursus: Jurnal Pendidikan Bahasa Indonesia, 2(03), 288. https://doi.org/10.30998/diskursus.v2i03.6708. 